\title{
Helcobacillus massiliensis gen. nov., sp. nov., a novel representative of the family Dermabacteraceae isolated from a patient with a cutaneous discharge
}

Correspondence

Véronique Roux

vroux91@hotmail.com

\author{
Aurélie Renvoise, Nicolas Aldrovandi, Didier Raoult and Véronique Roux
}

Laboratoire de Bactériologie - Virologie, Hôpital de la Timone, CNRS UMR 6236, CNRS-IRD, IFR48, 264 rue Saint-Pierre, 13385 Marseille, Cedex 05, France

\begin{abstract}
Gram-positive, non-spore-forming rods (strain $6401990^{\top}$ ), isolated from a human cutaneous discharge were subjected to a polyphasic taxonomy study. The only respiratory quinone was MK7 and the major fatty acids were anteiso-C15:0 (34.3\%), anteiso-C17:0 (18.7\%) and isoC16: 0 (18.6\%). Mycolic acids were not present. Polar lipids present were phosphatidylglycerol, diphosphatidylglycerol, phosphatidylethanolamine, phosphatidylcholine and unidentified glycolipids. The isomer of diaminopimelic acid identified was meso-diaminopimelic acid, and the analysis of whole-cell sugars showed the presence of high amounts of galactose, ribose and some glucose. The $\mathrm{G}+\mathrm{C}$ content of strain $6401990^{\top}$ was $68.6 \%$. Phylogenetic analysis based on 16S rRNA gene sequence comparisons showed $95.1 \%$ similarity with Dermabacter hominis. On the basis of phenotypic data and phylogenetic inference, it is proposed that this strain represents a novel species in a new genus of the family Dermabacteraceae, for which the name Helcobacillus massiliensis gen. nov., sp. nov. is proposed. The type strain is $6401990^{\top}$ (CSUR $\mathrm{P} 17^{\top}=\mathrm{CIP} 109418^{\top}=$ CCUG $53859^{\top}$ ).
\end{abstract}

The family Dermabacteraceae consists of Gram-positive, non-spore-forming, non-motile, rod-shaped bacteria that have DNA with a high G $+\mathrm{C}$ content (Stackebrandt et al., 1997). Presently, it includes the genera Dermabacter, Brachybacterium and a recently described genus Devriesea (Martel et al., 2008). Four strains were studied in 1988 and assigned to a novel genus and species, Dermabacter hominis (Jones \& Collins, 1988). These strains were isolated from human skin, but there was no evidence for the pathogenicity of the bacteria. In 1994, it was established that CDC group 3 and group 5 coryneform bacteria were members of the genus Dermabacter (Funke et al., 1994; Gruner et al., 1994). On the basis of DNA-DNA hybridization values, most of the strains were considered to belong to the species $D$. hominis. However, eight strains showed DNA-DNA hybridization values $<70 \%$ with $D$. hominis, but they were not included in other species because they could not be phenotypically differentiated. These strains were isolated from blood, establishing $D$. hominis as a potential human pathogen. In recent years, this bacterium was successively described in cerebral abscess (Bavbek et al., 1998), bacteraemias (Gómez-Garcés et al., 2001), peritoneal dialysis-associated peritonitis (Radtke et al., 2001) and chronic osteomyelitis (Van Bosterhaut et al., 2002),

Abbreviations: DAP, diaminopimelic acid; meso-Dpm, meso-diaminopimelic acid.

The GenBank accession number for the 16S rRNA gene sequence of Helcobacillus massiliensis strain $6401990^{\top}$ is EU477050. highlighting its role as an opportunistic pathogen. The genus Brachybacterium was proposed by Collins et al. (1988) and presently includes 12 recognized species. They were isolated from environmental samples (Brachybacterium faecium, Brachybacterium fresconis, Brachybacterium sacelli, Brachybacterium phenoliresistens and Brachybacterium zhongshanense), cheeses (Brachybacterium alimentarium and Brachybacterium tyrofermentans), corn steep liquor (Brachybacterium conglomeratum, Brachybacterium paraconglomeratum and Brachybacterium rhamnosum), milk (Brachybacterium nesterenkovii) and murine liver (Brachybacterium muris). Their implication in human pathology was not demonstrated. The genus Devriesea was recently proposed by Martel et al. (2008) and includes the species Devriesea agamarum associated with dermatitis and septicaemia in agamid lizards.

In this report, we attempted to elucidate the phylogenetic position of strain $6401990^{\mathrm{T}}$ which was isolated from a human cutaneous discharge sample. Using a polyphasic taxonomic approach, it is proposed that the isolate represents a novel genus of the family Dermabacteraceae.

A 58-year-old man was admitted to hospital in September 2006 for asthenia, myalgia and diffuse pain predominantly occurring in rachis, and presenting a chronic evolution over the course of 1 year. Antinuclear antibodies were weakly positive. A pathology such as connectivitis was suspected but could be neither confirmed nor eliminated. During his hospitalization, the patient presented an 
erythrasma. The cutaneous discharge sample was tested in our laboratory. The isolate was first identified as Corynebacterium minutissimum, using the miniaturized API Coryne strip (bioMérieux), but the phenotypic identification remained unclear. Consequently, genotypic identification was performed by $16 \mathrm{~S}$ rRNA gene sequence comparison and strain $6401990^{\mathrm{T}}$ was found to cluster in the Dermabacteraceae family close to Dermabacter hominis. The patient was empirically treated by oral erythromycin for 7 days. The erythrasma regressed quickly.

MICs were determined according to the disc diffusion method that we currently use in our laboratory, as there are, to our knowledge, no international guidelines for the antimicrobial susceptibility testing of coryneform bacteria. Strain $6401990^{\mathrm{T}}$ was found to be susceptible to amoxicillin, vancomycin, rifampicin, doxycycline and gentamicin, and intermediate to erythromycin.

Surface colonies on sheep blood agar (bioMérieux) were circular, white, shiny and smooth after $24 \mathrm{~h}$ aerobic incubation at $37{ }^{\circ} \mathrm{C}$. Growth and haemolytic activity were tested at $37{ }^{\circ} \mathrm{C}$ on Columbia agar with $5 \%$ sheep blood. Growth was tested after $24 \mathrm{~h}$ incubation at $37^{\circ} \mathrm{C}$, in the presence of air or $5 \% \mathrm{CO}_{2}$, and also in anaerobic and microaerophilic atmospheres which were created using GENbag anaer and GENbag microaer (bioMérieux), respectively. Growth at different temperatures $(25,30,37$, 44 and $50{ }^{\circ} \mathrm{C}$ ) was tested on Columbia agar for $24 \mathrm{~h}$. Optimum growth was obtained at $37^{\circ} \mathrm{C}$, but occurred between 25 and $44{ }^{\circ} \mathrm{C}$. The strain was aerobic and also grew in microaerophilia and in the presence of $5 \% \mathrm{CO}_{2}$. Growth in an anaerobic atmosphere was weak after $48 \mathrm{~h}$ incubation. The bacteria were non-haemolytic after $24 \mathrm{~h}$ incubation, but became alpha-haemolytic after $48 \mathrm{~h}$ incubation in the presence of air. The size and ultrastructure of cells were determined by transmission electron microscopy. Cells were grown in trypticase soy broth for $24 \mathrm{~h}$ at $37^{\circ} \mathrm{C}$. The bacterial suspension was pre-fixed in $5 \%(\mathrm{v} / \mathrm{v})$ glutaraldehyde in phosphate buffer (Gibco; KCl, $200 \mathrm{mg} \mathrm{l}^{-1}$; $\mathrm{KH}_{2} \mathrm{PO}_{4}, 200 \mathrm{mg} \mathrm{l}{ }^{-1} ; \mathrm{NaCl}, 8 \mathrm{~g} \mathrm{l}^{-1} ; \mathrm{Na}_{2} \mathrm{HPO}_{4} .7 \mathrm{H}_{2} \mathrm{O}$, $2.16 \mathrm{~g} \mathrm{l}^{-1}$ ) for at least $1 \mathrm{~h}$ at room temperature, washed in the same buffer and stained with $1 \%(\mathrm{w} / \mathrm{v})$ phosphotungstic acid. The samples were examined on a Morgagni 268D (Philips) electron microscope at an operating voltage of $60 \mathrm{kV}$. The rods were $0.7-1 \mu \mathrm{m}$ long and $0.4-0.7 \mu \mathrm{m}$ wide.

Catalase activity determined by the ID colour Catalase test kit (bioMérieux) was positive. Oxidase activity was assayed by applying the cells to moistened discs that were impregnated with dimethyl-p-phenylenediamine (bioMérieux) and was negative.

The commercially available API ZYM, API Coryne and API $50 \mathrm{CH}$ strips combined with API $50 \mathrm{CHB} / \mathrm{E}$ medium (bioMérieux) were used to characterize the biochemical properties of the strain according to the manufacturer's instructions, and incubation was performed at $37{ }^{\circ} \mathrm{C}$ for 4 , 24 and $72 \mathrm{~h}$, respectively. Phenotypic characteristics were compared to those of $D$. hominis CCUG $32998^{\mathrm{T}}$ which was the closest related species when 16S rRNA gene sequences were compared. Characteristic traits are presented in Table 1 . The results of the other tests for the type strain are given in the species description below.

The biochemical characteristics of strain $6401990^{\mathrm{T}}$ were also determined using the Biolog System. Bacterial growth was obtained on BUG (Biolog Universal Growth) agar + blood (Biolog) for $24 \mathrm{~h}$ at $37^{\circ} \mathrm{C}$. The bacterial suspension was prepared in sterile GP/GN inoculation fluid (Biolog) and inoculated into GP2 Microplates (Biolog; to study compounds as sole carbon sources) as described by the manufacturer. Incubation was carried out at $36{ }^{\circ} \mathrm{C}$ in an aerobic atmosphere for $21 \mathrm{~h}$. The results of the tests are given in the species description below.

Analysis of respiratory quinones by HPLC and polar lipids by two-dimensional TLC were carried out by the Identification Service and Dr Brian Tindall, DSMZ, Braunschweig, Germany. Respiratory lipoquinones were extracted from $100 \mathrm{mg}$ freeze-dried cell material as described by Tindall (1990a, b). Respiratory lipoquinones were separated into their different classes (menaquinones and ubiquinones) by TLC on silica gel, using hexane/terbutylmethylether $(9: 1, \mathrm{v} / \mathrm{v})$ as solvent. UV absorbing bands corresponding to menaquinones or ubiquinones were removed from the plate and further analysed by HPLC at $269 \mathrm{~nm}$. The only respiratory quinone was MK-7. Polar lipids were extracted from $100 \mathrm{mg}$ freeze-dried cell material using a chloroform/methanol $/ 0.3 \%$ aqueous $\mathrm{NaCl}$ mixture $(1: 2: 0.8$, by vol.; modified after Bligh \& Dyer, 1959). The extraction solvent was stirred overnight and the cell debris pelleted by centrifugation. Polar lipids were recovered into the chloroform phase by adjusting the chloroform/methanol $/ 0.3 \%$ aqueous $\mathrm{NaCl}$ mixture to a ratio of 1:1:0.9 (by vol.). Polar lipids were separated as described by Tindall et al. (2007). The polar lipids present were phosphatidylglycerol, diphosphatidylglycerol, phosphatidylethanolamine, phosphatidylcholine and unidentified glycolipids. Preparation and determination of cellular fatty acids were carried out by following the procedures given for the Sherlock Microbial identification System (MIDI). The major fatty acids were anteiso-C15:0 $(34.3 \%)$, anteiso-C17:0 (18.7\%) and iso-C16:0 (18.6\%). Mycolic acids were determined as described by Klatte et al. (1994) and were not detected. The DNA base composition was determined by using the HPLC method of Mesbah et al. (1989). The value for strain $6401990^{\mathrm{T}}$ was $68.6 \mathrm{~mol} \%$.

Whole cells of strain $6401990^{\mathrm{T}}$ were hydrolysed $(4 \mathrm{M} \mathrm{HCl}$, $100{ }^{\circ} \mathrm{C}, 16 \mathrm{~h}$ ) and the hydrolysate was subjected to TLC on cellulose plates using the solvent system of Rhuland et al. (1955). The isomer of diaminopimelic acid (DAP) identified was meso-diaminopimelic acid (meso-Dpm). For analysis of whole-cell sugars, cells were hydrolysed in $0.5 \mathrm{M} \mathrm{H}_{2} \mathrm{SO}_{4}\left(2 \mathrm{~h}\right.$ at $\left.100{ }^{\circ} \mathrm{C}\right) . \mathrm{H}_{2} \mathrm{SO}_{4}$ was removed according to the method of Whiton et al. (1985) and the 
Table 1. Diagnostic traits differentiating H. massiliensis $6401990^{\top}$ and $D$. hominis $\mathrm{CIP} 105144^{\top}$

+, Positive; -, negative; w, weak positive; DPG, diphosphatidylglycerol; PG, phosphatidylglycerol; PL, unidentified phospholipids; GL, unidentified glycolipid; PE, phosphatidylethanolamine; PC, phosphatidylcholine.

\begin{tabular}{|c|c|c|c|c|}
\hline \multirow[t]{2}{*}{ Character } & \multicolumn{2}{|c|}{ D. hominis } & \multicolumn{2}{|c|}{ H. massiliensis } \\
\hline & $48 \mathrm{~h}$ & $72 \mathrm{~h}$ & $48 \mathrm{~h}$ & $72 \mathrm{~h}$ \\
\hline \multicolumn{5}{|l|}{ Acid production from (API 50CH): } \\
\hline Glycerol & - & - & - & $\mathrm{w}$ \\
\hline Erythritol & - & - & - & + \\
\hline L-Arabinose & - & - & + & + \\
\hline D-Ribose & + & + & - & - \\
\hline D-Xylose & - & - & + & + \\
\hline D-Galactose & + & + & - & - \\
\hline Inositol & - & - & + & + \\
\hline D-Mannitol & - & - & + & + \\
\hline Methyl- $\alpha$-D-glucopyranoside & + & + & - & - \\
\hline Amygdalin & $\mathrm{W}$ & + & - & - \\
\hline Aesculin & + & + & - & - \\
\hline D-Lactose & + & + & - & - \\
\hline Melibiose & + & + & - & - \\
\hline Raffinose & + & + & - & - \\
\hline Gentiobiose & $\mathrm{w}$ & + & - & - \\
\hline \multicolumn{5}{|l|}{ Enzyme assay (API ZYM): } \\
\hline Esterase lipase (C8) & \multicolumn{2}{|c|}{+} & \multicolumn{2}{|c|}{-} \\
\hline Leucine arylaminidase & \multicolumn{2}{|c|}{+} & \multicolumn{2}{|c|}{-} \\
\hline$\beta$-Galactosidase & \multicolumn{2}{|c|}{+} & \multicolumn{2}{|c|}{-} \\
\hline$\beta$-Glucosidase & \multicolumn{2}{|c|}{+} & \multicolumn{2}{|c|}{-} \\
\hline$\alpha$-Mannosidase & \multicolumn{2}{|c|}{+} & \multicolumn{2}{|c|}{-} \\
\hline \multicolumn{5}{|l|}{ API Coryne strip: } \\
\hline Reduction of nitrate & \multicolumn{2}{|c|}{-} & \multicolumn{2}{|c|}{+} \\
\hline Pyrazinamidase & \multicolumn{2}{|c|}{-} & \multicolumn{2}{|c|}{+} \\
\hline Pyrrolidonyl arylaminidase & \multicolumn{2}{|c|}{+} & \multicolumn{2}{|c|}{-} \\
\hline Alkaline phosphatase & \multicolumn{2}{|c|}{$\mathrm{w}$} & \multicolumn{2}{|c|}{-} \\
\hline Gelatin hydrolysis & \multicolumn{2}{|c|}{-} & \multicolumn{2}{|c|}{+} \\
\hline Xylose fermentation & \multicolumn{2}{|c|}{-} & & \\
\hline Mannitol fermentation & & & & \\
\hline Ribose fermentation & & & & \\
\hline Predominant respiratory quinone & & & & \\
\hline $\mathrm{G}+\mathrm{C}$ content $(\mathrm{mol} \%)$ & & & & \\
\hline Polar lipids & & & DPG & GL \\
\hline Fatty acids (\%): & & & & \\
\hline anteiso-C17:0 & & & & \\
\hline anteiso-C15:0 & & & & \\
\hline
\end{tabular}

sugars in the hydrolysate were analysed by TLC on cellulose plates according to the method of Staneck \& Roberts (1974). High amounts of galactose, ribose and some glucose were found.

Bacterial DNA was extracted using the MagNA Pure LC DNA isolation kit III (Roche) with the MagNA Pure LC instrument, as described by the manufacturer.

PCR amplification of the 16S rRNA gene was performed using the universal primer pair $\mathrm{fD} 1$ and rp2 (Weisburg et al., 1991). PCR products were purified using MultiScreen PCR (Millipore) and sequencing reactions were carried out using a DNA sequencing kit (BigDye Terminator Cycle
Sequencing v1.1 Ready Reactions; PE biosystems), according to the manufacturers' instructions. Sequencing products were purified and electrophoresis was performed with the 3130 Genetic Analyzer (Applied Biosystems). The obtained sequences were compared with sequences deposited in the GenBank database by using the BLAST program through the NCBI server. Gene sequences were aligned using the multisequence alignment program CLUSTAL_X 1.8 (Thompson et al., 1997). Phylogenetic relationships with closely related species were determined by using MEGA version 4.0 (Tamura et al., 2007). Distance matrices were determined following the assumptions described by Kimura (1980) and were used to elaborate a dendrogram 
using the neighbour-joining method (Saitou \& Nei, 1987). The maximum-parsimony algorithm was also used to infer phylogenetic relationships. A bootstrap analysis (bootstrap values were obtained for a consensus tree based on 100 randomly generated trees) was performed to investigate the stability of the trees obtained. The clustering of the new isolate was the same with the two methods. The phylogenetic analysis demonstrated that our isolate clustered with $D$. hominis (Fig. 1). The percentage similarity between 16S rRNA gene sequences was determined by using LALIGN (www.ch.embnet.org/software/LALIGN form.html). The value between strain $6401990^{\mathrm{T}}$ and $D$. hominis was $95.1 \%$. This value is $<97 \%$ (which is the gold standard value to determine the species level) (Stackebrandt et al., 2002), confirming that strain $6401990^{\mathrm{T}}$ belongs to a novel species, but the different phenotypic characteristics implied that strain $6401990^{\mathrm{T}}$ did not belong to the genus Dermabacter.

Based on the results described above, we propose the name Helcobacillus massiliensis gen. nov., sp. nov. for the described bacterium. The type strain is $6401990^{\mathrm{T}}$.

\section{Description of Helcobacillus gen. nov.}

Helcobacillus (Hel.co.ba.cil'lus. Gr. n. helkos, wound; L. masc. n. bacillus, rod; N.L. masc. n. Helcobacillus, a $\operatorname{rod}$ found in wounds).

Gram-positive, non-spore-forming, non-motile, short rods. Essentially aerobic but may show very weak growth under anaerobic conditions. Optimum growth is obtained at $37{ }^{\circ} \mathrm{C}$. Catalase-positive and oxidase-negative. Acid is produced from glucose and some other sugars. Nitrate is reduced. Starch and aesculin are not hydrolysed. Gelatin is liquefied. Activities of $N$-acetyl- $\beta$-glucosaminidase, pyrazinamidase and $\alpha$-glucosidase are detected. The only menaquinone is MK-7. Predominant cellular fatty acids are anteiso-C15:0 (34.3\%), anteiso-C17:0 (18.7\%) and isoC16:0 (18.6\%). Mycolic acids are absent. Polar lipids are phosphatidylglycerol, diphosphatidylglycerol, phosphatidylethanolamine, phosphatidylcholine and unidentified glycolipids (phospholipid pattern III). The isomer of
DAP is meso-Dpm. Analysis of whole-cell sugars reveals high amounts of galactose, ribose and some glucose. The $\mathrm{G}+\mathrm{C}$ content of the genomic DNA of the type species is $68.6 \mathrm{~mol} \%$. The type species is Helcobacillus massiliensis.

\section{Description of Helcobacillus massiliensis sp. nov.}

Helcobacillus massiliensis (mas.si.li.en'sis. L. masc. adj. massiliensis of Massilia, the old Roman name for Marseille, where the type strain was isolated).

Cells are aerobic, Gram-positive, short, irregular, straight, non-spore-forming, and non-motile rods. Catalase-positive and oxidase-negative. Essentially aerobic but may show very weak growth under anaerobic conditions. Optimal growth occurs at $37^{\circ} \mathrm{C}$. After $24 \mathrm{~h}$ growth on sheep blood agar, surface colonies are up to $1 \mathrm{~mm}$ diameter, smooth, circular, white and shiny. The rods measure $0.7-1 \mu \mathrm{m}$ in length and $0.4-0.7 \mu \mathrm{m}$ in diameter (as determined by electron microscopy). Using API ZYM, activities of $N$ acetyl- $\beta$-glucosaminidase and $\alpha$-glucosidase are detected. Activities of leucine arylaminidase, valine arylaminidase, $\beta$ galactosidase, alkaline phosphatase, esterase (C4), esterase lipase (C8), lipase (C14), cystine arylaminidase, trypsin, $\alpha$ chymotrypsin, acid phosphatase, naphthol-AS-BI-phosphohydrolase, $\alpha$-galactosidase, $\beta$-glucuronidase, $\beta$-glucosidase, $\alpha$-mannosidase and $\alpha$-fucosidase are not detected. Using API 50CH strips after an incubation time of $48 \mathrm{~h}$, acid is produced from L-arabinose, D-xylose, D-glucose, Dfructose, inositol, D-mannitol, maltose, sucrose and turanose. After an incubation time of $72 \mathrm{~h}$, acid is produced (besides the characters previously quoted) from glycerol (weakly), erythritol, $\mathrm{N}$-acetylglucosamine (weakly), trehalose (weakly) and melezitose (weakly). Acid is not produced from D-arabinose, D-ribose, L-xylose, D-adonitol, methyl- $\beta$-D-xylopyranoside, D-galactose, Dmannose, L-sorbose, L-rhamnose, dulcitol, D-sorbitol, methyl- $\alpha$-D-mannopyranoside, methyl- $\alpha$-D-glucopyranoside, amygdalin, arbutin, aesculin ferric citrate, salicin, cellobiose, D-lactose, melibiose, inulin, raffinose, starch, glycogen, xylitol, gentiobiose, D-lyxose, D-tagatose, Dfucose, L-fucose, D-arabinol, L-arabinol, potassium

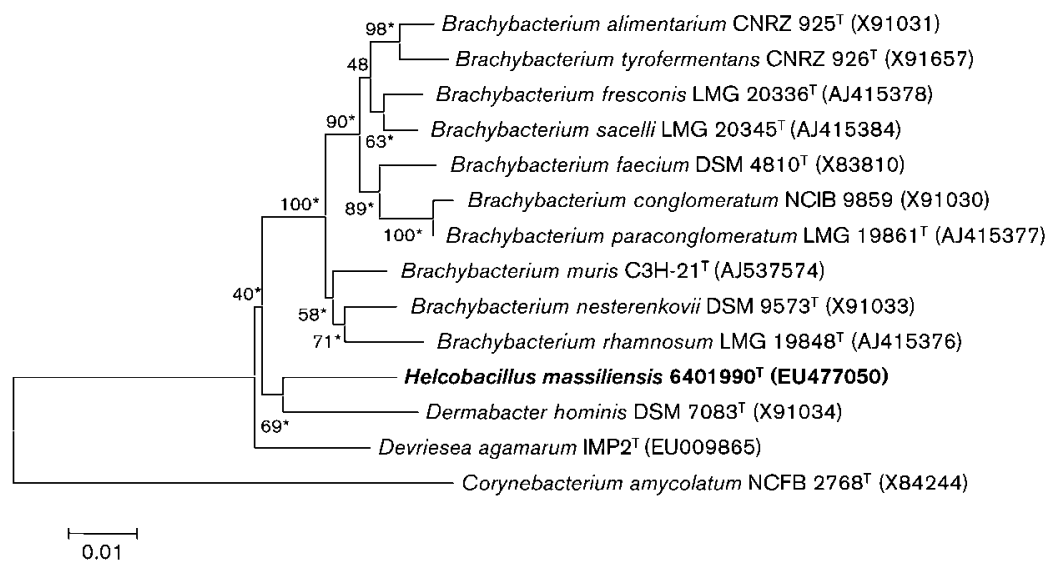

Fig. 1. Phylogenetic tree of representatives of the genera Brachybacterium, Devriesea, Dermabacter and Helcobacillus inferred from 16S rRNA gene sequence comparisons (1337 nt fragment) using the neighbourjoining method. Numbers at nodes are proportions of 100 resamplings that support the topology shown. Asterisks after the bootstrap values indicate the nodes that were also obtained in the maximum-parsimony tree. Corynebacterium amycolatum was used as the outgroup. Bar, 0.01 nucleotide changes per nucleotide position. 
gluconate, potassium 2-ketogluconate and potassium 5ketogluconate. Using API Coryne, the following tests are positive: $\alpha$-glucosidase, reduction of nitrate, pyrazinamidase, $N$-acetyl- $\beta$-glucosaminidase, gelatin hydrolysis, glucose, xylose, mannitol, maltose and sucrose fermentation. The others are negative: $\beta$-galactosidase, pyrolidonyl arylaminidase, alkaline phosphatase, $\beta$-glucuronidase, $\beta$ galactosidase, $\beta$-glucosidase, urease, ribose, lactose and glycogen fermentation. The compounds used as sole carbon sources recovered when using the Biolog System are: dextrin, $N$-acetyl-D-glucosamine, $N$-acetyl- $\beta$-D-mannosamine, L-arabinose, D-fructose, D-galactose, $\alpha$-D-glucose, m-inositol, maltotriose, D-mannitol, D-mannose (weakly), melezitose, 3-methylglucose, D-ribose, D-sorbitol, sucrose, trehalose, turanose, D-xylose, L-lactic acid, pyruvic acid methyl ester, L-alaninamide, D-alanine, L-alanine, Lalanylglycine, L-asparagine, L-glutamic acid, L-serine, glycerol, adenosine and thymidine. The following are negative: $\alpha$-cyclodextrin, $\beta$-cyclodextrin, glycogen, inulin, mannan, amygdalin, D-arabitol, arbutin, cellobiose, Lfucose, D-galacturonic acid, gentiobiose, D-gluconic acid, $\alpha$-D-lactose, lactulose, maltose, melibiose, $\alpha$-methyl-Dgalactoside, $\beta$-methyl-D-galactoside, $\alpha$-methyl-D-glucoside, $\beta$-methyl-D-glucoside, $\alpha$-methyl-D-mannoside, palatinose, D-psicose, raffinose, L-rhamnose, salicin, sedoheptulosan, stachyose, D-tagatose, xylitol, acetic acid, $\alpha$-hydroxybutyric acid, $\beta$-hydroxybutyric acid, $\gamma$-hydroxybutyric acid, $\mathrm{p}$ hydroxy-phenylacetic acid, $\alpha$-ketoglutaric acid, $\alpha$-ketovaleric acid, lactamide, D-lactic acid methyl ester, D-malic acid, L-malic acid, succinic acid mono-methyl ester, propionic acid, pyruvic acid, succinamic acid, succinic acid, $\mathrm{N}$-acetyl-L-glutamic acid, glycyl-L-glutamic acid, Lpyroglutamic acid, putrescine, 2,3-butanediol, 2'-deoxyadenosine, inosine, uridine, adenosine $5^{\prime}$-monophosphate, thymidine $5^{\prime}$-monophosphate, uridine $5^{\prime}$-monophosphate, D-fructose 6-phosphate, $\alpha$-D-glucose 1-phosphate, D-glucose 6-phosphate and DL- $\alpha$-glycerol phosphate. Utilization of the following is variable: Tween 40 and Tween 80 . The only respiratory quinone is MK-7 and polar lipids present are phosphatidylglycerol, diphosphatidylglycerol, phosphatidylethanolamine, phosphatidylcholine and unidentified glycolipids. The major fatty acids are anteiso-C15:0 $(34.3 \%)$, anteiso-C17:0 (18.7\%), iso-C16:0 (18.6\%), iso-C14:0 (9\%), $\mathrm{C} 18: 1 \omega 7 c$ and iso-C15:0 (5.2\%). Mycolic acids are absent. The isomer of DAP is mesoDpm. Analysis of whole-cell sugars shows high amounts of galactose, ribose and some glucose. The $\mathrm{G}+\mathrm{C}$ content of the genomic DNA is $68.6 \mathrm{~mol} \%$.

The type strain, which was isolated from a human cutaneous discharge sample, is $6401990^{\mathrm{T}} \quad(=\mathrm{CSUR}$ $\mathrm{P} 17^{\mathrm{T}}=$ CIP $109418^{\mathrm{T}}=$ CCUG $53859^{\mathrm{T}}$ ).

\section{References}

Bavbek, M., Caner, H., Arslan, H., Demirhan, B., Tunçbilek, S. \& Altinörs, N. (1998). Cerebral Dermabacter hominis abscess. Infection 26, 181-183.
Bligh, E. G. \& Dyer, W. J. (1959). A rapid method of total lipid extraction and purification. Can J Biochem Physiol 37, 911-917.

Collins, M.D., Brown, J. \& Jones, D. (1988). Brachybacterium faecium gen. nov., sp. nov., a coryneform bacterium from poultry deep litter. Int J Syst Bacteriol 38, 45-48.

Funke, G., Stubbs, S., Pfyffer, G. E., Marchiani, M. \& Collins, M. D. (1994). Characteristics of CDC group 3 and group 5 coryneform bacteria isolated from clinical specimens and assignment to the genus Dermabacter. J Clin Microbiol 32, 1223-1228.

Gómez-Garcés, J. L., Oteo, J., García, G., Aracil, B., Alós, J. I. \& Funke, G. (2001). Bacteremia by Dermabacter hominis, a rare pathogen. J Clin Microbiol 39, 2356-2357.

Gruner, E., Steigerwalt, A. G., Hollis, D. G., Weyant, R. S., Weaver, R. E., Moss, C. W., Daneshvar, M. \& Brenner, D. J. (1994). Recognition of Dermabacter hominis, formerly CDC fermentative coryneform group 3 and group 5, as a potential human pathogen. J Clin Microbiol 32, 1918-1922.

Jones, D. \& Collins, M. D. (1988). Taxonomic studies on some human cutaneous coryneform bacteria: description of Dermabacter hominis gen. nov., sp. nov. FEMS Microbiol Lett 51, 51-56.

Kimura, M. (1980). A simple method for estimating evolutionary rates of base substitutions through comparative studies of nucleotide sequences. J Mol Evol 16, 111-120.

Klatte, S., Kroppenstedt, R. M. \& Rainey, F. A. (1994). Rhodococcus opacus sp. nov., an unusual nutritionally versatile Rhodococcus species. Syst Appl Microbiol 17, 355-360.

Martel, A., Pasmans, F., Hellebuyck, T., Haesebrouck, F. \& Vandamme, P. (2008). Devriesea agamarum gen. nov., sp. nov., a novel actinobacterium associated with dermatitis and septicaemia in agamid lizards. Int J Syst Evol Microbiol 58, 2206-2209.

Mesbah, M., Premachandran, U. \& Whitman, W. B. (1989). Precise measurement of the $\mathrm{G}+\mathrm{C}$ content of deoxyribonucleic acid by high-performance liquid chromatography. Int J Syst Bacteriol 39, 159-167.

Radtke, A., Bergh, K., Øien, C. M. \& Bevanger, L. S. (2001). Peritoneal dialysis-associated peritonitis caused by Dermabacter hominis. J Clin Microbiol 39, 3420-3421.

Rhuland, L. E., Work, E., Denman, R. F. \& Hoare, D. S. (1955). The behavior of the isomers of $\alpha, \varepsilon$-diaminopimelic acid on paper chromatograms. J Am Chem Soc 77, 4844-4846.

Saitou, N. \& Nei, M. (1987). The neighbour-joining method: a new method for reconstructing phylogenetic trees. Mol Biol Evol 4, 406425.

Stackebrandt, E., Rainey, F. A. \& Ward-Rainey, N. L. (1997). Proposal for a new hierarchic classification system, Actinobacteria classis nov. Int J Syst Bacteriol 47, 479-491.

Stackebrandt, E., Frederiksen, W., Garrity, G. M., Grimont, P. A. D., Kämpfer, P., Maiden, M. C. J., Nesme, X., Rossello-Mora, R., Swings, J. \& other authors (2002). Report of the ad hoc committee for the re-evaluation of the species definition in bacteriology. Int $J$ Syst Evol Microbiol 52, 1043-1047.

Staneck, J. L. \& Roberts, G. D. (1974). Simplified approach to identification of aerobic actinomycetes by thin-layer chromatography. Appl Microbiol 28, 226-231.

Tamura, K., Dudley, J., Nei, M. \& Kumar, S. (2007). MEGA4: Molecular Evolutionary Genetics Analysis (MEGA) software version 4.0. Mol Biol Evol 24, 1596-1599.

Thompson, J. D., Gibson, T. J., Plewniak, F., Jeanmougin, F. \& Higgins, D. G. (1997). The CLUSTAL_X windows interface: flexible strategies for multiple sequence alignment aided by quality analysis tools. Nucleic Acids Res 25, 4876-4882. 
Tindall, B. J. (1990a). A comparative study of the lipid composition of Halobacterium saccharovorum from various sources. Syst Appl Microbiol 13, 128-130.

Tindall, B. J. (1990b). Lipid composition of Halobacterium lacusprofundi. FEMS Microbiol Lett 66, 199-202.

Tindall, B. J., Sikorski, J., Smibert, R. M. \& Krieg, N. R. (2007). Phenotypic characterization and the principles of comparative systematics. In Methods for General and Molecular Microbiology, 3rd edn, pp. 330-393. Edited by C. A. Reddy, T. J. Beveridge, J. A. Breznak, G. Marzluf, T. M. Schmidt \& L. R. Snyder. Washington DC: American Society for Microbiology.
Van Bosterhaut, B., Boucquey, P., Janssens, M., Wauters, G. \& Delmée, M. (2002). Chronic osteomyelitis due to Actinomyces neuii subspecies neuii and Dermabacter hominis. Eur J Clin Microbiol Infect Dis 21, 486-487.

Weisburg, W. G., Barns, S. M., Pelletier, D. A. \& Lane, D. J. (1991). 16S ribosomal DNA amplification for phylogenetic study. J Bacteriol 173, 697-703.

Whiton, R. S., Lau, P., Morgan, S. L., Gilbart, J. \& Fox, A. (1985). Modifications in the alditol acetate method for analysis of muramic acid and other neutral and amino sugars by capillary gas chromatography-mass spectrometry with selected ion monitoring. J Chromatogr 347, 109-120. 